\title{
Pengalaman, Usability, dan Antarmuka Grafis: Sebuah Penelusuran Teoritis
}

\author{
Ruly Darmawan \\ Fakultas Ilmu Seni Rupa dan Desain, \\ Institut Teknologi Bandung, Jalan Ganesa No. 10, Bandung 40132, Indonesia \\ E-mail: ruly.darmawan@gmail.com
}

\begin{abstract}
Abstrak. Pengalaman merupakan salah satu hasil yang diperoleh manusia dari interaksinya dengan lingkungan. Pengalaman ini memuat beragam hal yang dapat dipelajari, salah satunya adalah dalam mengetahui lebih jauh mengenai pemahaman mengenai manusia itu sendiri. Dari pemahaman ini dapat diuraikan beberapa pemahaman lanjutan, khususnya mengenai keperluan dasar manusia dalam menjalani aktifitas kesehariannya. Dalam konteks usability, faktor pengalaman ini memiliki andil dalam menentukan efektifitas dan efisiensi kerja sebuah sistem, produk teknologi, atau lingkungan. Makalah ini akan menelusuri bentuk pengalaman yang umum dimiliki manusia dan kemudian membahas relevansinya dengan konsep usability. Dalam upaya memperoleh pemahaman atas relevansi ini, dilakukan refleksi terhadap hasil pengamatan atas beberapa kasus antarmuka grafis (graphical user interface) yang berfungsi sebagai media antara manusia dengan sebuah produk atau sistem. Dari sini diharapkan diperoleh sebuah pemahaman yang baru yang melengkapi pendekatan usability yang sudah ada melalui penelusuran pengalaman manusia.
\end{abstract}

Kata kunci: antarmuka grafis; flow; konsep usability; pengalaman manusia.

Abstract. Experience is a significant matter for human beings. Man obtains as well as constructs the meaning of life through his very own experience. By investigating human experience, one can become fully aware of humanity, the world, and the mutual relationship between both entities. On the other hand, experience in relation to existence can also be investigated in a wider context. In the context of usability, investigation of experience can make a significant contribution, for example, when determining the effectiveness and efficiency of a system and/or a product of technology. This paper discusses human experience and then correlates it to the concept of usability. It includes observation of several graphical user interfaces that serve as a medium between people and a product or a system. The expected result is an understanding of experience that will complement the existing concept of usability.

Keywords: graphical user interface; interaction; usability; experience; flow

Received January $7^{\text {th }}, 2010$, Revised October $29^{\text {th }}, 2013$, Accepted for publication November $8^{\text {th }}, 2013$. Copyright $\odot 2013$ Published by LPPM ITB, ISSN: 1978-3078, DOI: 10.5614/itbj.vad.2013.4.2.1 


\section{Pendahuluan}

Dalam mempelajari tingkat efektifitas dan efisiensi manusia dalam melakukan pekerjaan yang mempergunakan alat, banyak upaya dan pendekatan yang dilakukan. Diantaranya dengan melakukan analisa pengguna dan tugas (user and task analysis), penggunaan kuesioner dan/atau wawancara, atau dengan melakukan pengamatan non-partisipan/non-partisipatif terhadap kerja manusia dalam mempergunakan sebuah produk atau sistem. Langkah pengukuran apapun yang dilakukan, tujuan akhirnya adalah diperolehnya catatan-catatan penting mengenai pengalaman manusia untuk ditindaklanjuti demi pengembangan dan perbaikan kualitas produk dan/atau sistem kedepannya.

Namun demikian, pengalaman pada manusia memiliki beragam dimensi pembahasan dan penelusurannya. Dari sejumlah ragam dimensi tersebut, masih memungkinkan seseorang untuk mencari asumsi-asumsi dasar mengenai pengalaman pada manusia atau yang dimiliki oleh manusia. Dari sini dapat ditelusuri dan diidentifikasi situasi-situasi yang mendasari manusia dan perwujudannya (embodiment), dimana hal ini dapat dimanfaatkan pula untuk dijadikan pendekatan dalam menilai atau mengukur kualitas sebuah produk atau sistem. Terlebih lagi dalam era teknologi informasi dan komunikasi seperti sekarang ini, pengalaman manusia sebagai salah satu parameter dalam membangun sebuah penilaian atas efektifitas dan efisiensi produk atau sistem, nampaknya perlu ditengok kembali. Berangkat dari pemahaman bahwa teknologi informasi merupakan teknologi pikiran (technology of the mind) dan memberikan peluang untuk mengirimkan, atau menyebarluaskan, aspek esensi diri (essential self) [1], maka perlu kiranya untuk melihat perspektif pengalaman dan usability sebuah produk atau sistem ini dalam sebuah konteks yang lebih luas lagi, dan melihat produk atau sistem teknologi informasi dan komunikasi sebagai salah satu wahana perwujudan manusia (human embodiment) daripada sekedar perangkat untuk membangun konektifitas dan aksesibilitas data melalui sebuah jejaring yang terintegrasi.

\section{$2 \quad$ Metodologi}

Penelusuran teoritis ini dimulai dengan membahas pengalaman dalam hubungannya dengan upaya manusia dalam perwujudan dirinya (embodiment). Penelusuran kemudian dilanjutkan dengan membahas konsep usability terlebih dahulu, termasuk faktor-faktor dalam usability itu sendiri. Penelusuran mengenai usability ini kemudian akan dikorelasikan dengan pembahasan pengalaman sehingga terjalin sebuah simpulan sinergis antara pemahaman tentang usability dan pengalaman manusia. Untuk memperoleh hasil yang lebih komprehensif, diambil beberapa kasus produk dengan batasan pada tampilan antarmuka grafis (graphical user interface) perangkat lunak. Tampilan 
antarmuka grafis yang dipilih secara acak adalah tampilan dari perangkat lunak yang umum dipergunakan ini, dan masing-masing dikomparasikan dengan kriteria:

1. tampilan antarmuka grafis dari perangkat lunak yang berbeda vendor dan fungsinya.

2. tampilan antarmuka grafis dari perangkat lunak yang sama vendor dan fungsinya, namun berbeda versi rilisnya.

\section{$3 \quad$ Hasil dan Pembahasan}

\subsection{Pengalaman Manusia}

Penginderaan manusia terhadap lingkungannya akan melahirkan pengalaman. Pengalaman ini kemudian menjadi sebuah tolok ukur manusia dalam melakukan aktifitas atau merespon segala sesuatunya di masa yang akan datang. Pengalaman disini tidak ubahnya seperti buku referensi yang memuat segala jenis informasi yang dibutuhkan untuk dijadikan landasan bagi manusia dalam mengambil sikap maupun keputusan dalam setiap segmen kehidupannya.

Pengalaman manusia ini telah banyak ditelaah oleh para pemikir dan banyak teori-teori yang dicetuskan yang merujuk kepada fenomena pengalaman ini dalam kehidupan manusia. Dalam tulisan ini, pengalaman bagi manusia dipahami sebagai sebuah upaya untuk memahami diri atau tubuhnya menuju sebuah perwujudan (embodiment). Perwujudan ini dalam pengertian yang salah satunya adalah representasi atas eksistensi manusia, yang mana masing-masing memiliki pengalaman yang berbeda dan unik satu sama lain. Melalui sebuah interview [2], diperoleh tiga kategori, berikut sub-kategorinya, yang menunjukkan keunikkan masing-masing individu dalam mengalami tubuhnya (experiencing the body), yaitu:

1. Experience of Engagement

2. Experience of Corporeality

3. Experience of Interpersonal Meaning

Experience of Engagement ini merupakan pengalaman yang berkaitan dengan momentum saat tubuh mengalami kontak (engage) dengan dunia luar atau lingkungannya. Dalam pengalaman ini situasi tubuh akan terkategorisasi menjadi dua sub-pengalaman, tubuh dalam vitalitas dan tubuh dalam aktifitas. Tubuh dalam vitalitas ini lebih kepada kontak secara non-fisik dengan lingkungan (seperti rasa sedih, rasa gembira), sementara tubuh dalam aktifitas lebih kepada kontak secara fisikal (seperti berlari, berjalan). 
Experience of Corporeality merupakan bentuk kesadaran akan tubuh secara fisik dan hadir sebagai obyek ataupun sebagai alat atau instrumen. Tubuh sebagai obyek merujuk kepada batasan-batasan yang dimiliki tubuh (seperti sakit, rasa kenyang), yang serupa dengan batasan yang dimiliki oleh obyek lain (seperti batasan dimensi). Melalui batasan ini, akan diperoleh mengenai eksistensi atau kesadaran akan tubuh itu sendiri. Adapun tubuh sebagai alat adalah sebuah rujukan kepada kesadaran bahwa tubuh ini merupakan media untuk mencapai suatu atau beberapa tujuan (seperti sebuah televisi yang tidak akan menyala sebelum tubuh ini bergerak dan menekan tombol "ON/OFF").

Experience of Interpersonal Meaning adalah sebentuk pengalaman dimana tubuh dipahami dalam konteks relasi sosial maupun relasi simbolis. Dalam kategori pengalaman ini, tubuh memiliki sub-kategori sebagai tampilan/ penampilan (appearance), dan sebagai ekspresi diri (self-expression). Pengalaman ini lebih membangun kesadaran manusia dalam sebuah situasi sosial dan upaya yang dilakukan dalam menempatkan diri dalam situasi sosial tersebut. Hal ini kemudian berhubungan pula dengan upaya manusia untuk menjawab pertanyaan: "bagaimana saya melihat diri saya", "bagaimana orang lain melihat saya", "bagaimana saya ingin dilihat orang lain".

Pada praktiknya, manusia mengalami pengalaman-pengalaman tersebut di atas sebagai satu set pengalaman penuh. Artinya, memungkinkan bagi manusia untuk mengalami satu atau lebih kategori pengalaman dengan kombinasi subkategori yang variatif. Disamping itu, pengalaman-pengalaman seperti di atas pada dasarnya merupakan potensi untuk dapat pula dijadikan sebagai salah satu alternatif pendekatan usability sebuah produk atau sistem.

\subsection{Usability dan Antarmuka Grafis (Graphical Interface)}

Interface atau antarmuka merupakan jembatan antara dunia sebuah produk atau sistem dan dunia pengguna [3]. Artinya, sebagaimana halnya proses komunikasi umum, antarmuka merupakan media yang menghubungkan komunikasi antara dua domain (produk/sistem dan manusia) dan berperan penuh dalam menerjemahkan setiap aksi dan reaksi dari kedua domain tersebut. Antarmuka berlaku pada beberapa jenis atau varian produk atau sistem. Dalam kehidupan sehari-hari, manusia dapat berinteraksi dengan obyek-obyek yang ada di sekitarnya melalui keberadaan antarmuka ini.

Dalam teknologi komputer, antarmuka salah satunya memiliki asosiasi dan fungsi sebagai media antara kode-kode komputasi dengan pengguna sebuah aplikasi atau perangkat lunak. Dalam hal ini, antarmuka bagi aplikasi tersebut memiliki beberapa jenis, yang salah satunya adalah antarmuka grafis (graphical interface). Dalam sebuah tampilan antarmuka grafis ini, kode-kode komputasi 
atas fungsi yang spesifik direpresentasikan melalui olahan elemen grafis seperti melalui ikon. Dari sinilah kemudian muncul persoalan usability. Usability berhubungan dengan efektifitas dan efisiensi dari antarmuka dan dengan reaksi pengguna terhadap antarmuka tersebut [4]. Sneiderman [4] mengidentifikasi usability berdasarkan kombinasi beberapa karakter yang berorientasi pengguna (user-oriented characteristics), yaitu:

1. ease of learning

2. high speed of user task performance

3. low user error rate

4. subjective user satisfaction

5. user retention over time

Dengan demikian, dapat dipahami bahwa usability hadir sebagai ukuran penerimaan (acceptance) seseorang terhadap sebuah produk atau sistem berdasarkan pemahaman dan ketepatan aksi/reaksi seseorang terhadap sebuah antarmuka. Tanggung jawab yang diemban sebuah desain antarmuka sangat besar di sini. Sebuah sistem yang mutakhir dengan antarmuka yang tidak mampu merepresentasikan fungsi-fungsi komputasi dibaliknya serta tidak dapat memenuhi aspek-aspek yang dibutuhkan manusia saat berinteraksi dengan antarmuka tersebut, dapat menyebabkan tidak diterimanya sebuah sistem oleh seseorang. Sebaliknya, sebuah sistem yang sederhana dengan antarmuka yang representatif terhadap fungsi-fungsi komputasi dan sanggup memberikan sarana yang mengakomodir aspek-aspek yang dibutuhkan manusia ketika berinteraksi dengan sebuah sistem, justru akan menjadi salah satu alasan diterimanya produk atau sistem tersebut oleh penggunanya. Lebih jauh lagi, antarmuka grafis ini memiliki nilai yang lebih dalam lagi mengingat adanya pemahaman Richard Coyne [1] sebelumnya dimana teknologi informasi pun memiliki nilai yang lebih dalam dan lebih luas bagi manusia.

\subsection{Relevansi Usability dan Pengalaman Manusia melalui Antarmuka Grafis}

Kombinasi beberapa karakter Sneiderman [4] tersebut secara umum dapat dipahami sebagai upaya untuk memperoleh efektifitas dan efisiensi produk atau sistem, utamanya ketika dipergunakan oleh manusia. Berangkat dari apa yang dikemukakan oleh Sneiderman [4] tersebut dapat dibangun korelasinya dengan pengalaman manusia, utamanya dalam konteks Experience of Corporeality dan salah satu butir lebih kepada konteks Experience of Engagement (Tabel 1).

Kategori Ease of learning dalam usability berkaitan dengan kategori tubuh sebagai obyek dan sebagai alat. Pada kategori ini, manusia hadir sebagai obyek yang memiliki batasan dalam arti manusia belum memiliki pengetahuan apa-apa mengenai sebuah sistem atau produk yang akan dipergunakannya, ataupun 
batasan untuk mengenali atau mengidentifikasi setiap obyek yang berbeda. Keberadaan referensi merupakan salah satu modal utama bagi manusia untuk membangun pemahamannya dan menjadikannya sebagai titik tolak dalam mempelajari sebuah sistem. Pada kategori ini pun manusia hadir sebagai alat dimana antarmuka grafis perlu mempermudah fungsi alat tubuh manusia sebagai bagian dari operasionalitas sebuah sistem atau produk. Dari penelusuran atas beberapa antarmuka grafis, kategori usability dan pengalaman ini diakomodir melalui kesamaan visual antar versi rilis. Dalam perangkat lunak yang dikembangkan oleh vendor berbeda pun mempertimbangkan kesamaan referensi visual dengan perangkat lunak vendor lain. Kesamaan referensi visual ini nampaknya berhubungan dengan kategori usability terakhir yaitu User Retention over Time. Artinya, sebuah tampilan antarmuka grafis harus mudah diingat dari waktu ke waktu sehingga tidak perlu lagi bagi seseorang untuk mengulang atau menyesuaikan diri kembali dengan lingkungan pekerjaannya melalui sebuah tampilan antarmuka grafis.

Tabel 1 Hasil Penelusuran atas Relevansi Usability dengan Sub-Pengalaman dari Experience of Corporeality.

\begin{tabular}{lc}
\hline \multicolumn{1}{c}{ Usability (Sneiderman) } & Kategori Sub-Pengalaman \\
\hline Ease of Learning & Tubuh sebagai obyek \\
& Tubuh sebagai alat (instrument) \\
High Speed of User Task & Tubuh sebagai alat \\
Performance & \\
Low User Error Rate & Tubuh sebagai obyek \\
Subjective User Satisfaction & Tubuh sebagai alat \\
& Tubuh dalam vitalitas \\
User Retention Over Time & (Experience of Engagement) \\
\hline
\end{tabular}

Kategori High Speed of User Task Performance dalam usability ini lebih memfokuskan diri kepada upaya akomodasi tubuh sebagai alat. Kemudahan operasional yang memungkinkan pengguna untuk memperoleh tingkat kecepatan dalam melakukan pekerjaannya. Tubuh sebagai alat membutuhkan kejelasan instruksi dalam setiap langkah proses pekerjaan. Melalui kejelasan instruksi inipun kecepatan kerja dapat diperoleh. Beberapa tampilan antarmuka grafis perangkat lunak memperlihatkan situasi yang memungkinkan seseorang untuk melakukan pekerjaannya secara cepat dan tepat melalui kejelasan instruksi atau representasi fungsi-fungsi komputasionalnya. Hal ini sebetulnya berkaitan dengan kategori berikutnya yaitu Low User Error Rate. Kejelasan instruksi akan mengurangi kesalahan pengguna dalam mengambil keputusan atau memilih fitur yang tersedia dalam sebuah tampilan antarmuka grafis. Di samping pertimbangan tubuh sebagai alat, kategori ini pun mempertimbangkan tubuh sebagai obyek dimana terdapat batasan-batasan bagi pengguna yang mana 
ketika batasan tersebut dilanggar akan besar kemungkinan kesalahan yang diperbuat.

Kategori Subjective User Expectation ini lebih kepada akomodasi dari kategori Experience of Engagement dengan sub kategori tubuh dalam vitalitas. Hal ini dikarenakan kepuasan lebih berada dalam sisi non-fisik atau batiniah manusia. Sehubungan dengan kepuasan ini, ada istilah WYSIWYG (What You See Is What You Get) atau apa yang kau lihat adalah sesuatu yang akan kau peroleh. Hal ini merupakan akomodasi pengembang perangkat lunak terhadap kepuasan pengguna. Utamanya dengan pekerjaan seputar manipulasi atau rekayasa visual, kesamaan kualitas pekerjaan ketika masih dalam proses dan ketika proses selesai (misalnya setelah dicetak) merupakan salah satu kunci utama kepuasan pengguna perangkat lunak grafis. Beberapa perangkat lunak telah memberikan kemungkinan bagi penggunanya untuk memperoleh beberapa kepuasan dalam proses kerja, maupun hasil dari proses pekerjaan itu sendiri.

\subsection{Flow}

Dari hasil penelusuran yang diperoleh tersebut, dapat disimpulkan juga bahwa masing-masing peran (penglaman, usability, dan antarmuka grafis) berfungsi untuk membangun sebuah FLOW. Flow secara etimologi berarti aliran. Namun Csikszentmihalyi memberikan arti definitif bagi flow ini sebagai sensasi menyeluruh yang dirasakan mereka ketika mereka beraksi dengan keterlibatan penuh [5]. Sederhananya, flow ini dapat dikatakan sebuah situasi dimana manusia memperoleh keselarasan dengan aktifitasnya, dengan lingkungannya. Hal senada pun dikemukakan oleh Edward T. Hall [6]. Hall melihat bahwa dalam kehidupan ini manusia memiliki potensi untuk menari. Menari di sini adalah sebuah metafora dari upaya sinkronisasi manusia dengan lingkungannya sehingga dihasilkan sebuah situasi yang selaras, harmonis. Sebagaimana dalam sebuah tarian, sang penari harus mampu merespon iringan musik, merespon gerakan penari lainnya, merespon arena tempat ia menari, dan sebagainya.

Dalam kasus ini, antara pengalaman, usability, dan antarmuka grafis berpotensi untuk membentuk flow. Flow yang terbentuk dalam konstelasi ini pada gilirannya nanti dapat dijadikan tolok ukur dalam membangun atau menentukan kualitas efektifitas dan efisiensi sebuah produk atau sistem. Dari beberapa kasus yang dipelajari, pengembang perangkat lunak mempertahankan sejumlah elemen dalam tampilan visual dari antarmuka grafis ini untuk membangun flow tersebut. Sehingga setiap perkembangan perangkat lunak tersebut selalu dapat diikuti dan dipelajari dengan baik oleh setiap penggunanya. 


\section{$4 \quad$ Kesimpulan}

Pengalaman manusia merupakan modal utama manusia dalam menjalani kehidupannya. Dalam konteks mengembangkan sebuah produk atau sistem, penelusuran atas pengalaman manusia bermanfaat untuk membuka pemikiranpemikiran kritis mengenai usability sebuah produk atau sistem. Manusia akan selalu berangkat dari pengalaman dalam memahami setiap situasi yang terjadi dalam kehidupannya. Dari penelusuran sebelumnya ditemukan bahwa affordances merupakan sebuah bentuk dari pengejawantahan atas sebuah konstelasi antara pengalaman, ekspektasi, dan visualisasi antarmuka grafis. Dari sini manusia akan mencoba memahami apa yang dilihatnya dalam sebuah tampilan antarmuka grafis sebelum menemukan sinergi macam apa yang dapat dilakukan oleh dirinya terhadap sebuah aplikasi, dan, sebaliknya, apa yang dapat dilakukan oleh sebuah aplikasi terhadap dirinya atau pekerjaan yang akan dilakukannya. Dari sini kemudian akan dihasilkan sebuah flow antara pengalaman manusia, usability, dan antarmuka grafis. Flow ini merupakan sebuah tarian manusia sebagai langkah sinkronisasi atau harmonisasi antara tubuhnya dengan lingkungannya, lebih spesifik lagi, antara tubuhnya dengan sebuah produk atau sistem.

\section{Referensi}

[1] Coyne, R.D. 1998. Cyberspace and Heidegger's Pragmatics, Information Technology and People, Special Issue: Heidegger and Information Technology, 11(4), hal.338-350.

[2] Gibbs, R.W., Jr. 2006. Embodiment and Cognitive Science, Cambridge University Press, New York.

[3] Hackos, J.T. \& Redish, J.C. 1998. User and Task Analysis for Interface Design, John Wiley \& Sons, inc., Toronto.

[4] Hix, D. \& Hartson, H.R. 1993. Developing User Interfaces: Ensuring Usability through Product \& Process, John Wiley \& Sons, inc., Toronto.

[5] Sato, I. 1988. Bosozoku: Flow In Japanese Motorcycle Gangs, dalam Csikszentmihalyi, M., Csikszentmihalyi, I.S. (ed), Optimal Experience: Psychological Studies of Flow in Conciousness, Cambridge University Press, Cambridge.

[6] Hall, E.T. 1983. The Dance of Life: The other Dimension of Time, Anchor Press/Doubleday, New York. 